\title{
Does Transfer Motivation Succeed in Mediating in the Context of Training Transfer?
}

\author{
Dida Sovia Wirdani ${ }^{1^{*}}$, Nury Ariani Wulansari ${ }^{2}$ \\ 1,2 Universitas Negeri Semarang \\ 1'didasovia17@gmail.com, 2nuryariani@mail.unnes.ac.id \\ ${ }^{*}$ Corresponding author
}

\begin{abstract}
The purpose of this study is to examine and find out the mediating effect of transfer motivation on the relationship between supervisor support and peer support on training transfers in Kantor Pelayanan Pajak (KPP) Pratama Semarang Timur and Selatan employees. This study took a sample of 130 employees by using proportional random sampling technique. The data collection method was carried out by means of a survey, namely interviews and questionnaires. The data analysis method uses descriptive statistical tests and partial least square. The results of this study were accepted both direct and indirect effects (mediation). The conclusion of this study is that KPP Pratama Semarang Timur and Selatan employees must improve the implementation of training results to work and believe that the successful implementation of knowledge, attitude skills can improve their performance.
\end{abstract}

Keywords: supervisor support, peer support, transfer motivation, training transfer

\begin{abstract}
Abstrak
Tujuan dari penelitian ini untuk menguji dan mengetahui efek mediasi dari motivasi transfer pada hubungan antara dukungan supervisor dan dukungan sebaya pada transfer pelatihan di Kantor Pelayanan Pajak (KPP) Pratama Semarang Timur dan karyawan Selatan. Sampel penelitian ini sejumlah 130 karyawan dan menggunakan teknik proporsional random sampling. Metode pengumpulan data yaitu survei, berupa wawancara dan kuesioner. Metode analisis data menggunakan tes statistik deskriptif dan partial least square. Hasil penelitian ini diterima baik efek langsung dan tidak langsung (mediasi). Kesimpulan dari penelitian ini adalah bahwa karyawan KPP Pratama Semarang Timur dan Selatan harus meningkatkan pelaksanaan hasil pelatihan untuk bekerja dan percaya bahwa keberhasilan penerapan pengetahuan, keterampilan sikap dapat meningkatkan kinerja mereka.
\end{abstract}

Kata kunci: dukungan atasan, dukungan rekan kerja, motivasi transfer, transfer pelatihan 


\section{INTRODUCTION}

The era of globalization has a significant impact on the company's life cycle. High quality human resources (HR) is a guide for every organization to achieve a goal (Sudarma, 2012). The solution to getting quality human resources is to provide training programs. The training program is used as a business solution to improve employee and company performance competency (Hurt, 2016), because training can support employee work productivity (Aspiyah \& Martono, 2016). In obtaining training effectiveness, training must be evaluated regularly, so that after training it must be ensured that there will be a transfer of learning and skills for employees (Martono \& Putri, 2018). Competencies and knowledge that have been obtained by employees will develop, if employees can apply it to work, so the training that has been followed by employees is considered effective (Bjerregaard, Haslam, \& Morton, 2016). Training transfer is the process of employees (trainees) taking back knowledge, skills and attitudes gained from training participation and then applying it to their work (Na-nan, Chaiprasit, \& Pukkeeree, 2017).

The factors of employees to be willing to transfer training are the work environment. This is because the work environment is a working condition to provide a comfortable climate and work situation of employees in achieving the desired goals of a company (Hairo \& Martono, 2019) including supervisor support, organizational support, peer support, technology support and opportunities for the need for knowledge gained (Ragini Chauhan et al., 2016; Noorizan et al., 2016). Supervisor support in general can be considered a positive work interaction between a supervisor and a subordinate (Nurlaila \& Sudarma, 2017). In this case, the supervisor provides an explanation of the role and value of a training and development as well as motivating employees to attend training and transferring the entire output of the training to completion of the task. (Al-Eisa et al., 2009). Support given by supervisor to employees in the form of giving advice, motivation to participate in training, providing innovation, acquiring employee knowledge, and giving awards to employees who have successfully carried out training transfers (Tracey \& Tews, 2005).

Another factor influencing employees to implement training output is peer support. Co-workers are members who involve themselves in a network that regularly meets, discusses and shares the results of the knowledge they have gained from training (Noe, 1998). Transfer of training will occur if a network of employees is established formally or informally (Ragini Chauhan et al., 2016). In addition, the ability to utilize the skills and abilities of members depends on the quality of the existing network (Yuniawan et al., 2017). So, co-workers are the triggers for the successful transfer of training. Previous research has proven that supervisor support and peer support influence the success of employees in applying training results to work (Bhatti et al., 2013; Suleiman et al., 2017; Muduli \& Raval, 2018). However, there are differences in results from other researchers who say that supervisor support and peer support has no effect on the transfer of training (Velada et al., 2007; Hua, 2013; Nurdiana, 2014). Thus, other researchers also questioned the reasons why supervisor support and peer support did not directly influence the transfer of training.

Recently there are results of research on training transfer which proves that the 
supervisor support and peer support is able to influence the training transfer variable but indirectly (Nijman \& Gelissen, 2011; Bhatti et al., 2013; Suleiman et al., 2017; Muduli \& Raval, 2018). The researcher explained that cause of supervisor support and peer support did not directly influence training transfer because there were other variables that functioned as mediators, it is transfer motivation (Muduli \& Raval, 2018). The existence of transfer motivation is often overlooked by researchers in studies measuring training effectiveness (Colquitt et al., 2000). Whereas, motivation is a process that affects the behavior and motivation that exists in someone who will create a behavior that is directed to achieve the final goal (Ranihusna, 2010). An example of motivation in this case is transfer motivation. Willingness of employees to use the knowledge and skills learned in training sessions to be applied into work (Muduli \& Raval, 2018).

Transfer motivation is also an important role in the training transfer process. Research has been proven by Muduli and Raval (2018) shows that transfer motivation has a significant positive effect on training transfer. Based on the problem, the purpose of this study is to re-test the transfer of training with the context of the research object and explore more in the role of mediation so whether the results will be the same or not. Based on the background above, the review of the literature is the following:

\section{METHOD}

This study examines the transfer of training to employees of the Kantor Pelayanan Pajak (KPP) Pratama in Semarang Timur and Selatan. The number of samples that researchers took was 130 respondents with proportional random sampling as a sampling technique. The 130 questionnaires returned were then filtered and examined for the completeness of the data.

The variable of this research is the training transfer using the instrument adopted by Tesluk al. (1995). Supervisor support variable using the instrument adopted by Chauhan et al. (2017). The peer support variable uses the instrument adopted by Chatterjee, Pereira, \& Sarkar (2016). The last variable is transfer motivation as mediation using the instrument adopted by Chatterjee et al. (2016). Each variable has an indicator namely: training transfer has 3 indicators with 5 statements, according to Tesluk et al. (1995) it is the use of new skills to improve performance, training helps improve performance, and Incorporate skills that have been learned into daily work. Indicators of supervisor support variable according to Chauhan et al. (2017) there are 4 indicators with 12 statements namely: support for the use of training in the workplace, direction of the use of training methods, barriers to use of training and informational support.

Indicator of the peer support variable according to Chatterjee et al. (2016) there are 3 indicators with 3 statements namely giving positive feedback, providing assistance and encouraging the application of training and expectations of performance development after conducting training. Then the indicator of the last variable is transfer motivation according Chatterjee et al. (2016) there are 3 indicators with 6 statements namely self-confidence to implement the results of training, the importance of training on performance, and the usefulness of training on task completion. 
This study uses data processing techniques with SEM method based on Partial Least Square (PLS) by assessing the Outer Model as well as to evaluate the reliability of construct variables in the analysis model. Figure 1 shows the path of the outer PLS model.

\section{Figure 1. Path Diagram of Output Model PLS}

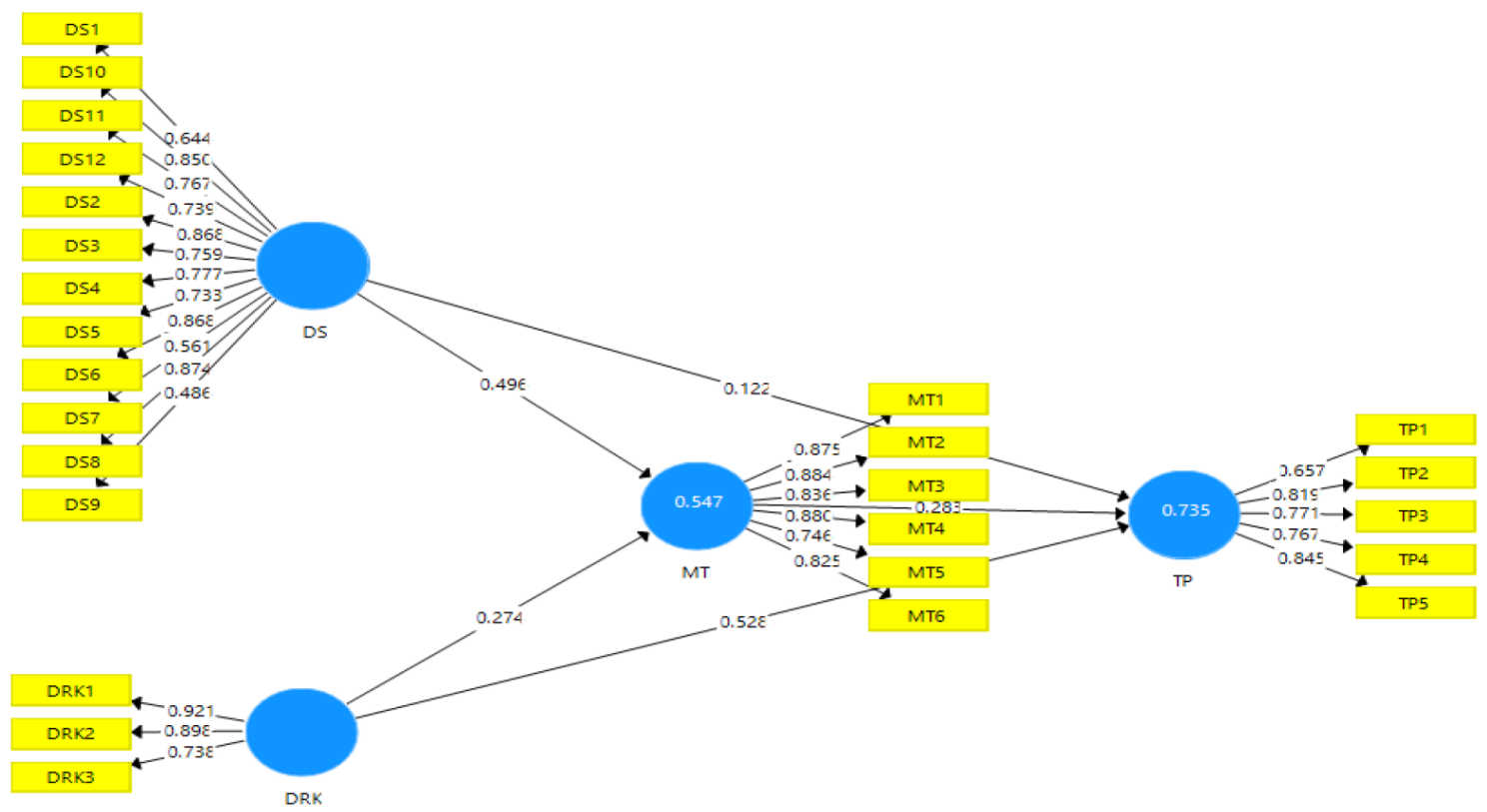

\section{RESULT AND DISCUSSION}

The coefficient of determination test aims to measure how far the ability of the independent variables simultaneously affects the dependent variable. The following results from the coefficient of determination test $\left(\mathrm{R}^{2}\right)$.

Table 1. R-Square $\left(\mathbf{R}^{2}\right)$

\begin{tabular}{cc}
\hline Variable & R-square \\
\hline Transfer Motivation & 0.520 \\
Training Transfer & 0.707 \\
\hline
\end{tabular}

Based on Table 1 shows that $52.0 \%$ of the variation in the value of transfer motivation can be explained by the support of supervisor and peer support, while the remaining $48.0 \%$ is explained by other variables outside the analysis model. The coefficient of determination of the transfer of training results in a value of $70.7 \%$, where the value indicates that $70.7 \%$ of the variation in the value of the transfer of training can be explained by transfer motivation, supervisor support and peer support while the remaining $29.3 \%$ is explained by other variables outside research analysis model. 
Table 2. Path Coefficient

\begin{tabular}{cccccc}
\hline Variable & $\begin{array}{c}\text { Original } \\
\text { Sample (O) }\end{array}$ & $\begin{array}{c}\text { Sample } \\
\text { Mean (M) }\end{array}$ & $\begin{array}{c}\text { Standard } \\
\text { Deviation }\end{array}$ & T-Statistics & P-Value \\
\hline SS - TT & 0,071 & 0,074 & 0,097 & 0,730 & 0,233 \\
SS - TM & 0,357 & 0,355 & 0,120 & 2,983 & 0,001 \\
PS - TM & 0,524 & 0,529 & 0,094 & 5,551 & 0,000 \\
PS - TM & 0,408 & 0,409 & 0,114 & 3,584 & 0,000 \\
TM - TT & 0,325 & 0,319 & 3,600 & 3,600 & 0,000 \\
\hline
\end{tabular}

Hypothesis testing is based on the Inner Model test results by taking into account the original sample, t-statistics and p-values. Hypothesis testing is divided into two, namely direct and indirect influences through the results of the bootstrapping test. The rule of thumb used in this study is t-statistic > 1,645 with a significance level of 5\% and a positive original sample (beta coefficient) value. Direct test results can be seen in the path coefficient.

Table 3. Total Indirect Effect

\begin{tabular}{cccccc}
\hline Variable & $\begin{array}{c}\text { Original Sample } \\
(\mathbf{O})\end{array}$ & $\begin{array}{c}\text { Sample } \\
\text { Mean (M) }\end{array}$ & $\begin{array}{c}\text { Standard } \\
\text { Deviation }\end{array}$ & T-Statistics & P-Value \\
\hline SS - TT & 0,116 & 0,111 & 0,045 & 2,607 & 0,005 \\
PS - TT & 0,133 & 0,132 & 0,057 & 2,334 & 0,01 \\
\hline
\end{tabular}

The support given by the leader has a relationship with the level of transfer of training. Supervisors have a positive influence on the ability of employees to transfer material or knowledge, skills and attitudes obtained in training for work completion in the office (Muduli \& Raval, 2018). Leaders have worked to increase the transfer of tax employee training in the workplace. Providing training to tax officials 2-3 times a year has carried out the form of efforts, but the training is not carried out internally, but is carried out centrally at the central office.

When colleagues at KPP Pratama Semarang Timur and Selatan fully support other colleagues to conduct training transfers, the success of other employees in implementing training results to the workplace will increase. Colleagues have sought to increase the transfer of tax employee training at the workplace. Forms of efforts that have been made by providing positive support and mutual understanding of the benefits of using knowledge and skills for the completion of office tasks. The results of this study were also supported by previous researchers who stated that peer support had a positive effect on the transfer of training (Na-nan et al., 2017; Muduli \& Raval, 2018).

When supervisors provide direction, positive and constructive support, and provide assistance in the form of joint discussions when employees experience difficulties in transferring training, then the employee will grow in self-motivation, confidence and desire to transfer training. The leader distributes work-related information to employees considered that the leadership had made the transfer motivation they had high because the leaders were willing 
to provide the information needed by the employees. Therefore, employees feel directed and clear with the job desk that will be completed by using the skills and knowledge that have been learned from the training. The results of this study are also supported by Bhatti et al. (2014) that states that superiors' support can influence employee motivation to be high and willing to transfer training.

When co-workers provide positive support, mutual confidence that the results of the training can be useful to improve performance, then employees who have attended the training will have high motivation to transfer the results of training to the workplace. Colleagues understand each other the employee who will use the new skills learned from the training. The results of this study are also supported by previous researchers who stated that coworkers provide high positive support to other coworkers able to influence motivation on these coworkers to transfer training results at work (Bhatti et al., 2013).

The higher the transfer motivation possessed by employe's, the successful process of implementing training results to the workplace will increase. The process of transferring training will be successful not only depends on the factors of leader and coworkers, but must be driven by personal factors such as transfer motivation because motivation is the main driver of one's behavior in a job (Martono et al., 2018). The greater the motivation of employees to transfer training results, the implementation of knowledge and skills learned will be successfully utilized to achieve the tax revenue target every month. Therefore, the Direktorat Jenderal Pajak asked all tax authorities to be able to take advantage of the results of training that have been followed for routine office work, such as providing tax payment services, to process tax revenue achievement targets properly.

The results of this study are also supported by previous studies that provide results of transfer motivation possessed by employees have a positive influence on the success of the process of transferring the results of training on work at work, which means high employee transfer motivation, the transfer of training will be successful too (Iqbal \& Dastgeer, 2015; Reinhold et al., 2018).

Total indirect effects show that transfer motivation is able to mediate the relationship between supervisor support and training transfer, then $\mathrm{H} 6$ is supported. That is, the more the boss increases providing support to employees, then making the motivation of employees to transfer training results will increase, this will also increase the successful implementation of training results or transfer training in the workplace. Leaders have encouraged their employees to attend training organized by the DJP, then supervised their employees when managing the results of the training that have been learned to the completion of work and provide guaranteed facilities. increase the transfer motivation. When the transfer motivation employees is high, it will have an impact on the transfer of training with increased results as well.

This study has answered the questions of previous researchers who suspected the lack of support from superiors in the transfer of training. It turns out that there is an intermediate factor of these two relationships, namely transfer motivation. The results of this study are also supported by previous research which states that superiors' support has an indirect influence on the transfer of training because there is an intermediate factor 
(mediation) which becomes the process of transferring training to be successful, namely transfer motivation (Suleiman et al., 2017; Reinhold et al., 2018).

The total indirect effects show that transfer motivation is able to mediate the relationship between peer supports on training transfer, then $\mathrm{H} 6$ is supported. That is, the more coworkers increase to provide support to employees, then the motivation of employees to transfer training results will increase, and this will also increase the successful implementation of training results or transfer training in the workplace. Employees will transfer training not only because of coworkers but there must be their own desire from employees to transfer training. When coworkers in a work team are less supportive and difficult to work with to transfer training, then employees must be able to control themselves to believe if the training results can be developed to achieve the targets and performance desired by superiors. This research is supported by a statement stating that work environment factors such as peer support are not enough to analyze the training transfer mode (Suleiman et al., 2017).

\section{CONCLUSION}

Based on the results of research that has been discussed that supervisor support has a positive effect on the transfer of training. Then, peer support has a positive effect on the transfer of training. Supervisor support has a positive effect on transfer motivation. On one hand, peer support has a positive effect on transfer motivation. This means that the positive and constructive support given by employees of KPP Pratama Semarang Timur and Selatan to other employees increases the motivation for employee transfers. Transfer motivation is able to mediate the relationship between supervisor support and training transfer and the relationship between peer support and training transfer. Because of this, the successful implementation of knowledge, skills and attitudes learned in training will succeed in improving employee performance.

This study provides suggestions for further research that is expected to further researchers who will examine the transfer of training are able to present other variables apart from work environment factors such as the support of superiors and coworkers. In addition, it raises indirect effects caused by factors other than personal factors (transfer motivation). Further researchers are also expected to conduct training transfer research on different research objects and respondents taken more specifically such as employees who have attended training for the past 6 months and so on.

\section{REFERENCES}

Al-Eisa, A. S., Furayyan, M. A., \& Alhemoud, A. M. (2009). An Empirical Examination of The Effects of Self-Efficacy, Supervisor Support and Motivation to Learn on Transfer Intention. Management Decision, 47(8), 1221-1244.

Aspiyah, M., \& Martono, S. (2016). Pengaruh Disiplin Kerja, Lingkungan Kerja dan Pelatihan pada Produktivitas Kerja. Management Analysis Journal, 5(4), 339-346.

Bhatti, M. A., Ali, S., Isa, M. F. M., \& Battour, M. (2014). Training Transfer and Transfer Motivation: The Influence of Individual, Environmental, Situational, Training Design, 
and Affective Reaction Factors. Performance Improvement Quarterly, 27(1), 51-82.

Bhatti, M. A., Battour, M. M., Sundram, V. P. K., \& Othman, A. A. (2013). Transfer of Training: Does it Truly Happen? An Examination of Support, Instrumentality, Retention and Learner Readiness on The Transfer Motivation and Transfer of Training. European Journal of Training and Development, 37(3), 273-297.

Bjerregaard, K., Haslam, S. A., \& Morton, T. (2016). How Identification Facilitates Effective Learning: The Evaluation of Generic Versus Localized Professionalization Training. International Journal of Training and Development, 20(1), 17-37.

Chatterjee, A., Pereira, A., \& Sarkar, B. (2016). Learning Transfer System Inventory (LTSI) and Knowledge Creation in Organizations. The Learning Organization, 1-16.

Chauhan, R, Ghosh, P., Rai, A., \& Kapoor, S. (2017). Improving Transfer of Training with Transfer Design: Does Supervisor Support Moderate The Relationship? Journal of Workplace Learning, 29(4), 1-24.

Chauhan, Ragini, Ghosh, P., \& Rai, A. (2016). The Impact of Support at The Workplace on Transfer of Training: A Study of an Indian Manufacturing Unit. International Journal of Training and Development, 20(3), 200-213.

Colquitt, J. A., Lepine, J. A., \& Noe, R. A. (2000). Toward an Integrative Theory of Training Motivation: A Meta-Analytic Path Analysis of 20 Years of Research. Journal of Applied Psychology, 85(5), 678-707.

Cowman, M. C., \& Mccarthy, A. M. (2016). The Impact of Demographic and Situational Factors on Training Transfer in a Health Care Setting. Irish Journal of Management, 35(2), 129-142.

Fitriani, Y., \& Wulansari, N. . (2018). Impact of Empowering Leadership on Employee Creativity by Motivationto to Learn and Trust in Leader as a Mediation. Management Analysis Journal, 7(2), 244-253.

Gegenfurtner, A. (2011). Motivation and Transfer in Professional Training: A Meta-Analysis of The Moderating Effects of Knowledge Type, Instruction, and Assessment Conditions. Educational Research Review, 6(3), 153-168.

Hairo, A. ., \& Martono, S. (2019). Satisfaction on Work Productivity. Management Analysis Journal, 8(1).

Hua, N. G. K. (2013). The Influence of Supervisory and Peer Support on The Transfer of Training. Studies in Business and Economics, 82-97.

Hurt, K. J. (2016). A theoretical model of training and its transference: the pivotal role of top management team composition and characteristics. Human Resource Development International, 1-24.

Iqbal, K., \& Dastgeer, G. (2015). Impact of Self Efficacy and Retention on Transfer of Training:The Mediating Role of Motivation to Transfer. Journal of Management Development, 6, 1-19.

Martono, S., Khoiruddin, M., \& Wulansari, N. . (2018). Remuneration Reward Management System as a Driven Factor of Employee Performance. International Journal of Business \& Society, 19, 535-545. 
Martono, S., \& Putri, V. . (2018). HRM Practices in Indonesia: the Contributing Power of Embeddedness and Support. Jurnal Dinamika Manajemen, 9(2), 206-217.

Muduli, A., \& Raval, D. (2018). Examining The Role of Work Context, Transfer Design and Transfer Motivation on Training Transfer. European Journal of Training and Development, 12(4), 1-18.

Na-nan, K., Chaiprasit, K., \& Pukkeeree, P. (2017). Influences of Workplace Environment Factors on Employees' Training Transfer. Industrial and Commercial Training, 2, 1-13.

Nijman, D., \& Gelissen, J. (2011). Supporting workplace learning, professional and practicebased learning 5. In Springer Science Business Media (pp. 89-106).

Noorizan, M. ., Afzan, N. ., Norfazlina, A. ., \& Akma, S. (2016). The Moderating Effects of Motivation on Work Environment and Training Transfer: A Preliminary Analysis. Procedia Economics and Finance, 37(16), 158-163.

Nurdiana, L. (2014). Pengaruh Dukungan Supervisor dan Dukungan Rekan Kerja Terhadap Transfer Pelatihan Karyawan Mekanik. Jurnal Ilmu Manajemen, 2(2), 675-686.

Nurlaila, F., \& Sudarma, K. (2017). Pengaruh Tuntutan Pekerjaan, Tipe Kepribadian Ekstrovert dan Dukungan Supervisor pada Kelelahan Emosional. Management Analysis Journal, 6(4), 423-434.

Pham, N. T. ., Segers, M. S. ., \& Gijselaers, W. H. (2012). Effects of Work Environment on Transfer of Training: Empirical Evidence from Master of Business Administration Programs in Vietnam. International Journal of Training and Development, 17(1), 1-19.

Ranihusna, D. (2010). Efek Rantai Motivasi Pada Kinerja Karyawan. Jurnal Dinamika Manajemen, 1(2), 90-103.

Reinhold, S., Gegenfurtner, A., \& Lewalter, D. (2018). Social support and motivation to transfer as predictors of training transfer: testing full and partial mediation using meta-analytic structural equation modelling. International Journal of Training and Development, 22(1), 1-14.

Sudarma, K. (2012). Mencapai Sumber Daya Manusia Unggul (Analisis Kinerja Dan Kualitas Pelayanan). Jurnal Dinamika Manajemen, 3(1), 76-83.

Suleiman, W., Dassanayake, M. ., \& Othman, A. E. A. (2017). Mediation of transfer motivation on the relationship between supervisor support, peer support and transfer of training. International Journal of Business and Society, 18(3), 605-617.

Switzer, K. C., Nagy, M. S., \& Mullins, M. E. (2005). The Influence of Training Reputation, Managerial Support, and Self-Efficacy on Pre-Training Motivation and Perceived Training Transfer. Applied Human Resource Management Research, 10(1), 21-34.

Tesluk, P. E., Farr, J. L., Mathieu, J. E., \& Vance, R. J. (1995). Generalization of Employee Involvement Training to The Job Setting: Individual and Situational Effects. Personn, 48, 607-632.

Tian, A. W., Cordery, J., \& Gamble, J. (2016). Returning The Favor: Positive Employee Responses to Supervisor and Peer Support for Training Transfer. International Journal of Training and Development, 20(1), 1-16.

Tracey, J. B., \& Tews, M. J. (2005). Construct Validity of a General Training Climate Scale. Organizational Research Methods, 8(4), 1-43. 
Velada, R., Caetano, A., Michel, J. W., Lyons, B. D., \& Kavanagh, M. J. (2007). The Effects of Training Design, Individual Characteristics and Work Environment on Transfer of Training. International Journal of Training and Development, 11(4), 282-294.

Yuniawan, A., Putri, V. W., \& Udin. (2017). Developing an Alternative Model for the Relationship among Social Capital, Adaptive-Integrative Leadership, Competitive Advantage, and Organizational Effectiveness. International Journal of Civil Engineering and Technology, $8(11), 52-60$. 